\title{
ARAŞTIRMA / RESEARCH \\ Gebeliğin ilk üç ayındaki kan TSH düzeyi ile Down sendromu tarama testleri arasındaki ilişki
}

\author{
Relationship between first trimester maternal TSH levels and Down syndrome \\ screening tests
}

Gökçen Örgül11, Devrim Rüzgar Doğan², Oytun Portakal², M.Sinan Beksaç1

${ }^{1}$ Hacettepe Üniversitesi Tip Fakültesi, Kadın Hastalıkları ve Doğum Anabilim Dalı, ${ }^{3}$ Tibbi Biyokimya Anabilim Dalı, Ankara, Türkiye

\begin{abstract}
Purpose: Down syndrome screening with first trimester combined test is recommended for all pregnancies. It is unclear, whether thyroid stimulating hormone (TSH) affects secretion of free beta subunit human chorionic gonadotropin ( $\mathrm{f} \beta-\mathrm{hcg}$ ) and pregnancy-related plasma protein (PAPP-A). We aimed to investigate the effect of serum thyroid stimulating hormone (TSH) levels on the combined test results.
\end{abstract}

Materials and Methods: First trimester TSH levels together with nuchal translucency $(\mathrm{NT} / \mathrm{f} \beta-\mathrm{hcg}$ and PAPP A results of 297 patients were included in this study. Patients were divided into four groups according to their TSH levels; Group $1(<0.1 \mu \mathrm{L} / \mathrm{ml})$, Group 2 (0.1-2.5 $\mu \mathrm{lU}$ $/ \mathrm{ml})$, Group $3(2.5-3.5 \mu \mathrm{lU} / \mathrm{ml})$ and Group 4 (> $3.5 \mu \mathrm{lU}$ $/ \mathrm{ml})$. Groups were compared in terms of NT, PAPP-A and $\mathrm{f} \beta$-hcg levels.

Results: The mean PAPP-A (MoM) value was found to be 0.99 in group 1, 1.12 in group 2, 1.03 in group 3, and 0.95 in group 4. Mean $\mathrm{f} \beta$-hcg $(\mathrm{MoM})$ value was 1.36 in group 1, 1.29 in group 2, 1.05 in group 3, and 1.32 in group 4. The mean NT measurement was $1.27 \pm 0.25$, $1.33 \pm 0.38,1.34 \pm 0.33$ and $1.32 \pm 0.37 \mathrm{~mm}$, from group 1 to group 4, respectively. There was no statistically significant difference between groups in terms of PAPP-A, $\mathrm{f} \beta$-hcg and NT.

Conclusion: The present study have shown that first trimester TSH levels do not affect combined test parameters. Prenatal screening by using NT, f $\beta-h C G$ and PAPP-A seems to be safe for pregnant women with hypothyroidism or hyperthyroidism.

Key words: Pregnancy-associated plasma protein-A, nuchal translucency, human chorionic gonadotropin, thyroid stimulating hormone
$\mathrm{Oz}$

Amaç: Illk üç ayda tüm gebelere Down Sendromu taraması amaciyla kombine test yapılması önerilmektedir. Tiroid stimulan hormonun (TSH) serbest beta subünit human koriyonik gonadotropin ( $\mathrm{f} \beta-\mathrm{hcg})$ ve gebelik ile ilişkili plazma protein A (PAPP-A) üretimini etkileyip etkilemediği net değildir. Bu çalışmada serum TSH düzeylerinin kombine test sonuçları üzerine etkisinin olup olmadığını araştırmayı amaçladık.

Gereç ve Yöntem: İlk trimester TSH değeri ile birlikte ense saydamlığ $(\mathrm{NT})$, $\mathrm{f} \beta$-hcg ve PAPP-A sonuçlarına ulaşılabilen 297 hasta çalışmaya dahil edilmiştir. Hastalar TSH değerlerine göre dört gruba ayrılmıștır; Grup $1(<0.1$ $\mathrm{uIU} / \mathrm{ml})$, Grup $2(0.1-2,5 \mathrm{uIU} / \mathrm{ml})$, Grup $3(2.5-3.5$ $\mathrm{uIU} / \mathrm{ml})$ ve Grup 4 (>3.5 uIU/ml). Gruplar NT, PAPP-A ve $\mathrm{f} \beta$-hcg düzeyleri açısından karşılaş̧ırılmıştır.

Bulgular: Ortalama PAPP-A (MoM) değeri grup 1'de 0.99, Grup 2'de 1.12, Grup 3'de 1,03 ve Grup 4'de 0,95 olarak tespit edilmisstir. Ortalama $\mathrm{f} \beta$-hcg $(\mathrm{MoM})$ değeri ise grup 1'de 1.36, Grup 2'de 1.29, Grup 3'de 1.05 ve Grup 4'de 1.32 idi. Ortalama NT ölçümü grup 1'den grup 4'e doğru gittikçe sırasıyla $1.27 \pm 0.25,1.33 \pm 0.38,1.34 \pm$ 0.33 ve $1.32 \pm 0.37 \mathrm{~mm}$ olarak saptanmıştır. Gruplar arasında PAPP-A, $\mathrm{f} \beta$-hcg ve NT açısından istatistiksel olarak anlamlı bir fark olmadığı gösterilmiştir.

Sonuç: Illk trimester TSH düzeylerinin kombine test parametrelerini etkilemediği gösterilmiştir. Hipotiroidisi veya hipertiroidisi olan kadınlarda NT, $\mathrm{f} \beta-\mathrm{hCG}$ and PAPPA kullanılarak prenatal tarama testi yapılmasının güvenli olduğu düşünülmüștür.

Anahtar kelimeler: Gebelikle ilişkili plazma protein-A, nukal saydamlık, human koriyonik gonadotropin, tiroid stimulan hormon 


\section{GİRİŞ}

Prenatal dönemde başta trizomi 21 (Down sendromu, DS) olmak üzere anöploiditaraması yaşa bakılmaksızın tüm gebelerde önerilmektedir. Günümüzde tarama testi olarak birçok farklı yöntem kullanılabilmektedir ${ }^{1-3}$. Ilk trimesterde kombine test /ikili test ile ikinci trimesterde ise üçlü/dörtlü test ile maternal kandaki biyobelirteçler aracilığıyla risk hesaplaması yapılabilmektedir. Kombine test için ultrasonografi aracılığıyla ölçülen ense saydamlığı (NT) ile birlikte maternal kanda bakilan human koriyonik gonadotropin (HCG)'nin serbest beta alt birimi (f $\beta-h c g)$ ve gebelik ile ilişkili plazma protein A (PAPP-A) düzeyleri kullanılmaktadır ${ }^{4}$. Kombine testin trizomi 21'i saptama oranı (detection rate) oldukça yüksektir $(\% 90)$, ancak $\% 5$ yanlış pozitiflik oranı da akılda tutulmalıdır ${ }^{5}$.

Gebeliğin ikinci üç ayında ise üçlü veya dörtlü test ile risk hesaplaması yapılabilmektedir. Üçlü test bileşenleri alfa-fetoprotein (AFP), serbest estriol (uE3) ve total hCG olup; teste inhibin A eklenmesi halinde dörtlü test olarak adlandırılmaktadır ${ }^{6}$. Trizomi 21 için üçlü ve dörtlü testlerin tayin oranları kombine teste göre daha düşüktür; sırasıyla \%65-70 ve $\% 70-75{ }^{\prime} \mathrm{dir}^{5}$. Günümüzde invaziv olmayan prenatal tarama testi (NIPT) de klinik uygulamada yer almaya başlamıştır. Bu testte anne plazmasından serbest fetal DNA fragmanları (cff-DNA) elde edilerek özel bir takım teknikler kullanılarak dizileme işlemi yapılmaktadır; trizomi 21 ve 18 için tayin oranı $\% 98$ iken trizomi 13 için $\% 90$ olarak bildirilmiştir, yanlış pozitiflik oranı ise $\% 0,5$ 'in altındadır ${ }^{7}$. Yüksek saptama oranı ve düşük yalancı pozitiflik oranları sayesinde NIPT ile gereksiz koryonik villus örneklemesi ve amniosentez gibi girişimsel işlemlerinin önüne geçilmiş olur.. Yüksek maliyetli olması ve ulaşılabilirliğinin kısıtlı olması sebebiyle yalnızca yüksek riskli gebelere (kendisinde veya ailesinde trizomili bebek öyküsü olması, ileri anne yaşı, vb.) yapılması önerilmektedir. Ülkemizde günlük pratikte NIPT testleri yerine daha az maliyeti olması sebebiyle kombine test veya üçlü test tercih edilmektedir ${ }^{8,9}$.

Anne yaşı, NT, $f \beta$-hcg ve PAPP-A birlikte kullanıldığında DS'lu fetusların yakalanma oranı $\% 90$ kadar olup kombine testin yalanc1 pozitiflik oranı $\% 5$ civarındadır. Anlamlı bir sonuç elde edilmesi için testin gebeliğin 11 ile 14. haftaları arasında yapılması önem taşımaktadır ${ }^{4}$. Gebelikte sinsityotrofoblastlar ve desidua tarafindan üretilen glikoprotein yapıdaki PAPP-A, plasental glukoz ve aminoasit transportu ve etkili trofoblast invazyonunda önemli rol oynamaktadır. Fizyolojik etkilerini insulin like growth factor (IGF) biyoyararlanımını artırarak gerçekleştirdiği düşünülmektedir ${ }^{10}$. Gebeliğin oluşması ve devam etmesinde önemli rolü olan hCG birbirine nonkovalant olarak bağlı $\alpha$ and $\beta$ subünite taşıyan bir glikoproteindir. Sinsityotrofoblastlar tarafindan üretilen bu hormonun en önemli görevi endometriyumun mitotik büyümesi ve farklılaşması, maternal immun sistemin baskılanmasi ve uterus boyutunun artırılması olduğu bilinmektedir ${ }^{11}$.

Tiroid hormonu üretimi açısından kritik öneme sahip tiroid stimulan hormon (TSH) ile $\beta$-hcg yapisal olarak birbirlerine benzemektedirler. Alfa subünite yap1s1 aynı olan bu iki hormonun beta subüniteleri farklı yapıda olup, $\beta$-hcg zayıf tiroid stimulan etkiye sahiptir. Bu sebeple ilk trimesterdeki artan $\beta$-hcg piki geçici bir subklinik hipertiroidi tablosuna yol açabilmektedir ${ }^{12}$. Sağlıklı gebeliklerde tiroksin (T4) plasenta aracilığıla fetusa transfer edilmekte ve fetal hücrelerde bir takım yolaklar ile triiodotiroksin (T3)'e dönüştürülmektedir. Erken gebelik haftas1 plasentalarında T3 ve T4'ün progesteron, estradiol 17-beta, hCG, ve human plasental laktogen sekresyonunu artırdığı in vitro çalışmalarda gösterilmiştir ${ }^{13}$.

Kombine test sonuçlarının yanlış pozitifliği anksiyete ve gereksiz invaziv işlemler ile ilişkilidir. . Maternal TSH ve tiroid hormon düzeylerinin $\beta$-hcg ve PAPPA sekresyonunu etkileyip etkilemediği net değildir. $\mathrm{Bu}$ sebeple bu çalışmamızda birinci trimester serum TSH düzeylerinin kombine test sonuçları üzerine etkisinin olup olmadığını araştırmayı amaçladık.

\section{GEREÇ VE YÖNTEM}

Hacettepe Üniversitesi Tip Fakültesi Hastanesi kadın hastalıkları ve doğum polikliniğe Ocak 2014 Aralık 2017 tarihleri arasında başvuran toplam 1500 gebeye ait veriler retrospektif olarak taranmıştır.Ek hastalığ1 olan, sigara içen, bilinen diyabet gibi risk faktörleri olan anneler ve çoğul gebelikler çalışmaya dahil edilmemişlerdir. Bunun yanı sıra yapısal veya kromozomal anomali saptanan fetuslar da çalışma dışı bırakılmıştır. İlk trimester TSH değeri ile birlikte kombine test sonuçlarına ulaşılabilen 297 hasta çalışma grubunu oluşturmaktadır.

Birinci trimester kombine testte yer alan biyokimyasal parametreler, (serbest beta-HCG ve 
PAPP-A), IMMULITE 2000 (Siemens Healthcare Diagnostics,UK) analizöründe kemiluminesan metotla ölçüldü. PRISCA programı ile NT ve biyokimyasal parametrelerin MoM değerleri saptandi ve Trizomi 21, 18, 13 için risk hesaplaması yapıldı. Risk kestirim değeri Trizomi 21 için 1:250 ve Trizomi 18 için 1:100 seçildi.

Kliniğimizin rutin uygulamasında ilk trimesterde gebelerden tam kan sayım1, TSH, anti-Rubella IgG, HbsAg ve anti-HIV testleri istenmektedir. Bununla birlikte tüm tekil gebeliklerde 11 ile 13 hafta 6 gün arasinda kombine test ile prenatal tarama testi yapılmaktadır. Kombine test için ultrasonografi ile NT ölçümünü takiben maternal kandan $f \beta-h c g$ ve PAPP-A aynı gün içerisinde bakılarak risk değerlendirilmesi yapılmaktadır.

Anne yaşı, ağırlık ve gebelik öyküsü gibi maternal verilere hasta epikrizlerinden ulaşılmı̧tır. Bilgisayar sisteminden ulaşılan kombine test sonuçlarından ise kan alındığı andaki gebelik haftası, baş popo mesafesi (CRL) ölçümü, NT değeri gibi bilgiler elde edilmiştir. İkili test sonuçlarında mevut olan PAPP$A$ ve $f \beta-h c g$ değerleri hem sayısal hem de MoM değerleri açısından değerlendirilmiştir.

Gebelikte TSH'ın normal kabul edildiği referans aralığ ilk trimester için 0,1-2,5 uIU/ml'dir 14. Bizim çalışmamızda bu doğrultuda hastalar TSH değerlerine göre dört gruba ayrılmıştır; Grup $1(<0,1$ $\mathrm{uIU} / \mathrm{ml})$, Grup 2 (0,1-2,5 uIU/ml), Grup 3 (2,5-3,5 $\mathrm{uIU} / \mathrm{ml})$ ve Grup $4(>3,5 \mathrm{uIU} / \mathrm{ml})$. Gruplar NT, PAPP-A ve $\mathrm{f} \beta$-hcg düzeyleri açısından karşılaştırılmıştır.

\section{İstatistiksel analiz}

Elde edilen veriler SPSS (Statistical Package for the Social Sciences) versiyon 23 kullanılarak analiz edilmiştir. Çalışmadan elde edilen verileri değerlendirilirken tanımlayıcı istatistiksel yöntemler (ortalama, standart sapma, ortanca) kullanılmıştır. Gruplardaki veriler ise Kruskal-Wallis testi kullanılarak karşılaştırılmıştır. $\quad \mathrm{p}<0.05$ düzeyleri anlamlı olarak değerlendirilmiştir.

\section{SONUÇ}

Çalışma grubunda yer alan gebelere ait demografik veriler Tablo 1.de verilmiştir. Tüm olgular birlikte değerlendirildiğinde ortalama anne yaşı $30.49 \pm$ 4.67'idi. Kombine test yapılma haftas 11 ile 13 hafta 6 gün arasında değişmekte olup ortalama 12 hafta olarak saptanmıştır.

Gebelerin TSH düzeyine göre sinıflandırılmas1 sonucunda Grup 1'de 16, Grup 2'de 224, Grup 3'te 38 ve Grup 4'te 19 olgu saptanmıştır. İkili test parametreleri (PAPP-A ve $\mathrm{f} \beta$-hcg ) açısından gruplar arasında istatistiksel olarak anlamlı bir fark olmadığı görülmüştür (Tablo 2). Ortalama PAPP-A (MoM) değeri grup 1'de 0.99, Grup 2'de 1.12, Grup 3'de 1.03 ve Grup 4'de 0.95 olarak tespit edilmiştir. Ortalama $\mathrm{f} \beta$-hcg $(\mathrm{MoM})$ değeri ise grup 1'de 1.36, Grup 2'de 1.29, Grup 3'de 1.05 ve Grup 4'de 1.32 idi. Ortalama NT ölçümü grup 1'den grup 4'e doğru gittikçe sırasıly $1.27 \pm 0.25,1.33 \pm 0.38,1.34 \pm$ 0.33 ve $1.32 \pm 0.37 \mathrm{~mm}$ olarak gösterilmiştir.

Tablo 1. Çalışma grubunda yer alan olguların klinik ve laboratuvar bulguları.

\begin{tabular}{|c|c|c|c|}
\hline & & -Ortalama (std) & -Ortanca (min-max) \\
\hline \multirow[t]{5}{*}{ Anne bilgileri } & Anne Yaş1 & $30.49 \pm 4.67$ & $30.7(18-41)$ \\
\hline & Ağırlık (kg) & $65.96 \pm 65.96$ & $64(32-109)$ \\
\hline & Gravida & $2.13 \pm 1.18$ & $2(1-6)$ \\
\hline & Parite & $0.77 \pm 0.88$ & $1(0-5)$ \\
\hline & Abortus & $0.36 \pm 0.73$ & $0(0-5)$ \\
\hline \multirow[t]{3}{*}{ Fetal veriler } & Gebelik haftası & $12.2 \pm 0.4$ & $12(11-136 / 7)$ \\
\hline & CRL $(\mathrm{mm}) *$ & $57.63 \pm 8.18$ & $57.9(49-80)$ \\
\hline & $\mathrm{NT}(\mathrm{mm}) \dagger$ & $1.33 \pm 0.37$ & $1.3(0.6-3.2)$ \\
\hline \multirow[t]{5}{*}{ Laboratuvar değerleri } & TSH (uIU $/ \mathrm{ml}) \ddagger$ & $1.66 \pm 1.72$ & $1.4(0.1-20)$ \\
\hline & PAPP-A $(\mathrm{mIU} / \mathrm{ml}) \mathbb{S}$ & $2.91 \pm 1.94$ & $2.41(0.46-15.8)$ \\
\hline & PAPP-A (MoM) & $1.09 \pm 0.62$ & $0.94(0.22-4.48)$ \\
\hline & $\mathrm{f} \beta$-hcg $\beta$-hcg (ng/ml) II & $51.63 \pm 43.34$ & $38.9(8.86-511)$ \\
\hline & $\mathrm{f} \beta-\mathrm{hcg} \beta-\mathrm{hcg}(\mathrm{MoM})$ & $1.27 \pm 1.04$ & $0.98(0.24-11.65)$ \\
\hline
\end{tabular}

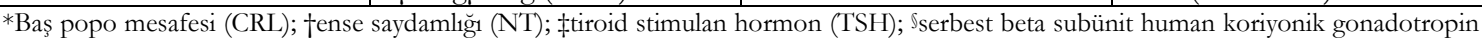
$(\mathrm{f} \beta-\mathrm{hcg} \beta-\mathrm{hcg})$; I gebelik ile ilişkili plazma protein A (PAPP-A)

Tablo 2.Gruplardaki ikili test parametrelerinin karşıllaştırılması. 


\begin{tabular}{|c|c|c|c|c|c|}
\hline & $\begin{array}{c}\text { Grup } 1 \\
(\mathrm{TSH}<0,1 \\
\mathrm{uIU} / \mathrm{ml})\end{array}$ & $\begin{array}{c}\text { Grup 2 } \\
\text { (TSH 0,1-2,5 } \\
\text { uIU/ml) }\end{array}$ & $\begin{array}{c}\text { Grup 3 } \\
\text { (TSH 2,5-3,5 } \\
\text { uIU/ml) }\end{array}$ & $\begin{array}{c}\text { Grup } 4 \\
(\mathrm{TSH}>3,5 \\
\mathrm{uIU} / \mathrm{ml})\end{array}$ & $\mathrm{p}$ \\
\hline Hasta say1s1 & 16 & 224 & 38 & 19 & \\
\hline PAPP-A * $(\mathrm{mIU} / \mathrm{ml})$ & $2.62 \pm 1.75$ & $3.01 \pm 2.05$ & $2.76 \pm 1.48$ & $2.42 \pm 1.39$ & 0.659 \\
\hline PAPP-A* (MoM) & $0.99 \pm 0.65$ & $1.12 \pm 0.66$ & $1.03 \pm 0.42$ & $0.95 \pm 0.52$ & 0.376 \\
\hline $\mathrm{f} \beta-\mathrm{hcg} \beta-\mathrm{hcg}+(\mathrm{ng} / \mathrm{ml})$ & $58.05 \pm 32.35$ & $52.78 \pm 46.42$ & $41.36 \pm 23.01$ & $53.29 \pm 44.29$ & 0.219 \\
\hline
\end{tabular}

* gebelik ile ilişkili plazma protein A (PAPP-A); ${ }^{\dagger}$ serbest beta subünit human koriyonik gonadotropin (f $\beta$-hcg); ${ }^{\ddagger}$ nukal translusensi (NT).

\section{TARTIŞMA}

Biyokimyasal belirteçlerin kullanıldı̆̆ı prenatal tarama testleri birçok ülkede rutin klinik uygulamanın bir parçası haline gelmiştir. Fetal anomalierin erken tanısı ailelere gebeliğin devamı ya da sonlandırılması kararı açısından zaman kazandırmaktadır. Terminasyon kararı alındığında ise erken dönemde yapılacak işlemler anne açısından daha güvenilir olmaktadır. Tüm bu sebeplerden ötürü ilk trimester tarama testleri ve bu testlerin güvenilirliği önem taşımaktadır 15,16. Ülkemizde Sağlık Bakanlığ1 tarafindan hazırlanan "Doğum Öncesi Bakım Yönetim Rehberi"nde kromozomal anöploidi tarama testleri ve ultrasonografi incelemeleri hakkında ailelerin bilgilendirilmesi önerilmektedirAyrıca, bu rehber tüm gebelere 11-14 haftalar arasinda ultrasonografi ile ense saydamlığının ölçülerek kombine test uygulanmasını, eğer bu test yapılamamışsa 16-20 haftalar arasında üçlü/dörtlü test uygulanmasını önermektedir ${ }^{17}$.

Anne kanındaki PAPP-A konsantrasyonu fetal kandan yüz kat, amniyotik sıvıdan ise bin kat daha yüksektir. Sağlıklı gebeliklerde maternal dolaşımdaki PAPP-A düzeyleri gebelik haftası ile birlikte artmaktadır. İlk trimesterde 3-4 günde ikiye katlanarak artan PAPP-A seviyeleri, doğuma kadar artmaya devam etmektedir ${ }^{18}$. Erken gebelikte düşük PAPP-A düzeylerinin intrauterin gelişim geriliği, preeklampsi, gibi anormal plasenta fonksiyonu ile ilişkili olduğu gösterilmiştir. Başta DS olmak üzere trizomi 18, trizomi 13 gibi fetal anöploidilerde ve düşük doğum ağırlığı gibi durumlarda yine maternal PAPP-A seviyeleri düşüktür ${ }^{10,19}$.

Gebelikte serum $\beta$-hcg seviyeleri 8-10 haftada en yüksek seviyesine ulaşıp sonrasında bir miktar düşer ve doğuma kadar plato çizer. Anormal $\beta$-hcg düzeylerinin gebelik komplikasyonları ile ilişkili olduğu bilinmektedir. Özellikle 2 MoM üzerindeki değerlerde preeklampsi i, erken doğum, düşük doğum ağırlı̆̆1, fetal ölüm ve hipertansiyon riski artmaktadır ${ }^{20}$. Trizomi 2'1li trofoblastlardaki artan $\beta$-hcg sekresyonu ise moleküler çalışmalar yardımıyla gösterilmiştir. Plasentanın immatürasyonu nedeniyle kontrol mekanizmasının bozulması $\beta$-hcg üretiminin sürekli devam etmesi ile sonuçlanmaktadır ${ }^{21}$.

Sağlıklı bir gebelikte artan metabolik ihtiyacın karşılanması amacıyla tiroid fizyolojisinde bir takım değişiklikler meydana gelir. Serum tiroksin bağlayıcı globülin (TBG) seviyesinde artış ve $\beta$-hcg'nin stimulasyonu ile TSH reseptörlerinde artan uyarılar en temel değişikliklerdir 22. Maternal TSH düzeylerinin sağlıklı ve DS'lu fetusa sahip gebelerde karşılaştırıldığ1 bir çalışmada iki grup arasında istatistiksel olarak anlamlı bir fark olmadığ görülmüştür. Serum TSH seviyelerinin trizomi 21 belirteci olarak kullanımının faydalı olmayacağı gösterilmiştir ${ }^{23}$. Bizim çalışmamızda DS'lu fetus taşıyan anneler çalışma dışı bırakılmıştır. Bu sayede kafa karışıklığına yol açabilecek gerçek pozitif test sonuçları analiz edilmemiştir. Çünkü bu grupta TSH düzeyinden bağımsız olarak altta yatan etiyoloji sebebiyle PAPP-A ve $\beta$-HCG düzeyleri gruplar arasında farklı olacaktır.

İlk trimester serum belirteçlerinin maternal tiroid hormonları ile ilişkisi Aytan ve arkadaşları tarafından incelenmiştir. $\mathrm{Bu}$ doğrultuda $\mathrm{TSH}$, serbest $\mathrm{T} 4$, serbest T3, total T4 ve total T3 düzeylerinin $\mathrm{f} \beta$-hcg ve PAPP-A kan seviyelerini etkilemediği gösterilmiştir 24. Bizim çalışmamızda da TSH seviyelerine göre olgular sinıflandırıldığında; gruplar arasinda NT, s $\beta$-hCG and PAPP-A düzeyleri açısından istatistiksel olarak anlamlı bir fark olmadığı gösterilmiştir. Çalışma sonuçlarımız literatür ile birlikte değerlendirildiğinde; serbest $\beta$-hCG ve PAPP-A değerlerinin TSH düzeylerinden etkilenmediği sonucuna varılmıştır.

Ashoor ve arkadaşları tarafindan yapılan bir çalışmada, trizomi 21, trizomi 18 ile sağlıklı fetuslardaki maternal tiroid fonksiyon testleri karşılaştırılmıştır. Serum TSH düzeyleri trizomi 21'lerde en düşük olup trizomi 18'lerde en yüksek 
bulunmuştur. Fakat bu artışı NT, free $\beta$-hCG ve PAPP-A ile yapilan kombine test performans1 üzerine etkisi olmadığı gösterilmiştir ${ }^{25}$. Bir başka çalışmada tiroid fonksiyon testlerinin eklenmesinin kombine test sonuçları üzerine etkisi araştırılmıştır. Yüzde 85 prenatal DS tanı oranı için NT, free $\beta$ hCG ve PAPP-A'ya TSH ve serbest T4 eklenmesi ile yanlış pozitiflik oranının \%5.3'ten \%3.6'a düştüğü gösterilmiştir ${ }^{26}$. Tüm bu sonuçlar göstermektedir ki; ikili test parametreleri TSH düzeylerinden etkilenmemektedir.

Çalışmamızın geriye dönük dosya taraması yöntemiyle yapılmış olması, toplam hasta sayısının göreceli olarak az olması ve gruplardaki hasta dağılımının eşit olmaması çalışmamızın en temel kısıtlılıklarıdır. Birden fazla merkezin katılımıla yapilacak ve tiroid hormon parametrelerinin tamamının (TSH, T3, T4, tiroid antikorlarının) analiz edileceği bir çalışma ile daha fazla bilgiye ulaşılabilir.

Çalışmamızdan elde edilen sonuçlara göre, maternal TSH düzeylerinin gebeliğin ilk üç ayında yapılan DS tarama testleri üzerine bir etkisi olmadığ1 gösterilmiştir. Sonuç olarak, hipotiroidisi veya hipertiroidisi olan kadınlarda NT, serbest $\beta$-hCG ve PAPP-A kullanılarak prenatal tarama testi güvenle kullanılabilir.

\section{KAYNAKLAR}

1. Egan JF, Kaminsky LM, DeRoche ME, Barsoom MJ, Borgida AF, Benn PA. Antenatal Down syndrome screening in the United States in 2001: a survey of maternal-fetal medicine specialists. Am J Obstet Gynecol. 2002;187:1230-34.

2. Karadeniz RS, Altay M, Karasu Y, Gelișen O, Haberal A. Comparison of triple and qadrupple test in second trimester Down syndrome screening. Gynecol Obstet Reprod Med. 2009;15(1).

3. Graham L. ACOG releases guidelines on screening for fetal chromosomal abnormalities. Am Fam Physician 2007.

4. Canick JA, Kellner LH. First trimester screening for aneuploidy: serum biochemical markers. Semin Perinatol. 1999;25:359-68.

5. Ehrich M, Deciu C, Zwiefelhofer T, Tynan JA, Cagasan L, Tim R et al. Noninvasive detection of fetal trisomy 21 by sequencing of DNA in maternal blood: a study in a clinical setting. Am J Obstet Gynecol. 2011;204:201-5.

6. Alldred SK, Deeks JJ, Guo B, Neilson JP, Alfirevic Z. Second trimester serum tests for Down's Syndrome screening. Cochrane Database Syst Rev. 2012;13:CD009925.
7. Bianchi DW, Platt LD, Goldberg JD, Abuhamad AZ, Sehnert AJ, Rava RP. Genome-wide fetal aneuploidy detection by maternal plasma DNA sequencing. Obstet Gynecol . 2012;119:890-901.

8. Ökem ZG, Örgül G, Kasnakoglu BT, Çakar M, Beksaç MS. Economic analysis of prenatal screening strategies for Down syndrome in singleton pregnancies in Turkey. Eur J Obstet Gynecol Reprod Biol . 2017;219:40-4.

9. Bianchi DW, Parker RL, Wentworth J, Madankumar $\mathrm{R}$, Saffer C, Das AF et al. DNA sequencing versus standard prenatal aneuploidy screening. $\mathrm{N}$ Engl J Med. 2014;370:799-808.

10. Shiefa S, Amargandhi M, Bhupendra J, Moulali S, Kristine T. First trimester maternal serum screening using biochemical markers PAPP-A and free $\beta$-hCG for down syndrome, patau syndrome and edward syndrome. Indian J Clin Biochem. 2013;28:3-12.

11. Stenman U-H, Tiitinen A, Alfthan H, Valmu L. The classification, functions and clinical use of different isoforms of HCG. Hum Reprod Update. 2006;12:769-84.

12. Ballabio M, Poshyachinda M, Ekins RP. Pregnancyinduced changes in thyroid function: role of human chorionic gonadotropin as putative regulator of maternal thyroid. J Clin Endocrinol Metab. 1991;73:824-31.

13. Maruo $\mathrm{T}$, Matsuo $\mathrm{H}$, Mochizuki M. Thyroid hormone as a biological amplifier of differentiated trophoblast function in early pregnancy. Acta Endocrinol. 1991;125:58-66.

14. Seven A, Kucur SK, Polat M, Yüksel B, Işıklar Ö, Keskin N. Gebelerde birinci trimester tiroid fonksiyon testi sonuçlarının değerlendirilmesi. Muğla Sitk1 Koçman Üniversitesi Tip Dergisi. 2016;3:5-8.

15. Nicolaides KH. Nuchal translucency and other firsttrimester sonographic markers of chromosomal abnormalities. Am J Obstet Gynecol. 2004;191:4567.

16. Malone FD, Canick JA, Ball RH et al. First-trimester or second-trimester screening, or both, for Down's syndrome. N Engl J Med.. 2005;353(19):2001-11.

17. Doğum Öncesi Bakım Yönetim Rehberi. Ankara, T.C. Sağlık Bakanlığı, 2014.

18. Bischof P, Amaudruz M, Weil-Franck C, Baeriswyl JP, Weil A, Hermann WL et al. The disappearance rate of pregnancy-associated plasma protein-A (PAPP-A) after the end of normal and abnormal pregnancies. Arch Gynecol. 1984;236:93-8.

19. Gagnon A, Wilson RD, Audibert F et al. Obstetrical complications associated with abnormal maternal serum markers analytes. J Obstet Gynaecol Can. 2008;30:918-32.

20. Gravett CP, Buckmaster JG, Watson PT, Gravett MG. Elevated second trimester maternal serum $\beta$ HCG concentrations and subsequent adverse pregnancy outcome. Am J Med Genet A. 1992;44:485-6. 
21. Eldar-Geva T, Hochberg A, DeGroot N, Weinstein D. High maternal serum chorionic gonadotropin level in Downs' syndrome pregnancies is caused by elevation of both subunits messenger ribonucleic acid level in trophoblasts. J Clin Endocrinol Metab. 1995;80:3528-31.

22. Yoshimura M, Hershman JM. Thyrotropic action of human chorionic gonadotropin. Thyroid. 1995;5:42534.

23. Weinans MJ, Pratt JJ, de Wolf BT, Mantingh A. First-trimester maternal serum human thyroidstimulating hormone in chromosomally normal and
Down syndrome pregnancies. Prenat Diagn. 2001;21:723-5.

24. Aytan H, Caliskan AC, Demirturk F, Sahin S, Erdogan F, Kuzu Z. Relationship between maternal thyroid hormones and the biochemical markers of the first trimester aneuploidy screening. Arch Gynecol Obstet. 2013;287:1125-9.

25. Ashoor G, Maiz N, Cuckle H, Jawdat F, Nicolaides $\mathrm{KH}$. Maternal thyroid function at 11-13 weeks of gestation in fetal trisomies 21 and 18. Prenat Diagn. 2011;31:33-7.

26. Dhaifalah I, Salek T, Langova D, Cuckle H. Incorporating thyroid markers in Down syndrome screening protocols. Prenat Diagn. 2017;37:510-4. 